\title{
Analisis Persetujuan Klaim BPJS Kesehatan pada Pasien Rawat Inap
}

\author{
Muhammad Tijar Gifari ${ }^{1}$, Fajar Ariyanti ${ }^{2}$ \\ ${ }^{1,2}$ Program Studi Kesehatan Masyarakat, Fakultas IImu Kesehatan \\ Universitas Islam Negeri Syarif Hidayatullah Jakarta \\ Jl. Kertamukti, Pisangan, Ciputat, Kota Tangerang Selatan, Banten 15419 \\ Email: ${ }^{1}$ tijargifari@hotmail.com, ${ }^{2}$ fajar.ariyanti@uinjkt.ac.id
}

\begin{abstract}
Abstrak
Untuk mencapai prinsip pelaksanaan JKN yang efektif, BPJS kesehatan melakukan pembiayaan pelayanan kesehatan dengan sistem paket INA CBG's kepada penyedia fasilitas kesehatan tingkat lanjut, salah satunya adalah Rumah Sakit Umum Daerah (RSUD) Tangerang Selatan. Di dalam proses verifikasi klaim BPJS ternyata terdapat banyak kendala yang terjadi salah satunya adalah penolakan berkas oleh verifikator yang dapat berdampak pada potensi adanya gangguan operasional rumah sakit. Kelengkapan informasi rekam medis dan ketepatan kode diagnosa menjadi faktor yang mempengaruhi klaim BPJS. Penelitian ini bertujuan untuk menganalisa gambaran persetujuan klaim BPJS kesehatan meliputi kelengkapan informasi, ketetapan diagnosis, dan persetujuan klaim BPJS. Penelitian ini adalah penelitian Cross sectional deksriptif dengan menggunakan data sekunder berupa data rekam medis pasien rawat inap RSUD Tangerang Selatan periode Januari-Maret 2019. Hasil penelitian menunjukkan $65,9 \%$ informasi rekam medis lengkap 87,6\% diagnosis utama tepat, dan 85,7\% klaim BPJS kesehatan disetujui. Disarankan kepada pihak manajemen RSUD Tangerang Selatan untuk memperhatikan faktor-faktor yang menyebabkan klaim ditolak seperti kelengkapan informasi rekam medis dan ketepatan kode diagnosis utama guna mengurangi angka klaim yang ditolak pada klaim BPJS Kesehatan.
\end{abstract}

Kata Kunci: BPJS, Klaim, Kelengkapan, Ketepatan, Persetujuan

\begin{abstract}
To achieve the principle of effective JKN implementation, the Health BPJS carries out financing for health services using the INA CBG package system to advanced health facility providers, one of which is the South Tangerang Regional General Hospital (RSUD). In the BPJS claim verification process, it turns out that there are many obstacles that occur, one of which is the rejection of a file by a verifier that can have an impact on the potential for disruption of hospital operations. The completeness of medical record information and the accuracy of the diagnostic code are factors that influence BPJS claims. This study aims to analyze the picture of BPJS health claims approval including the complete information, diagnosis determination, and BPJS claim approval. This research is a descriptive cross sectional study using secondary data in the form of inpatient medical records in South Tangerang Hospital in the January-March 2019 period. The results showed 65.9\% complete medical record information $\mathbf{8 7 . 6 \%}$ precise primary diagnosis, and $85.7 \%$ of BPJS health claims approved. It is recommended to the management of South Tangerang Regional Hospital to pay attention to the factors that cause claims to be rejected such as the completeness of medical record information and the accuracy of the main diagnosis code in order to reduce the number of claims rejected on BPJS Health claims.
\end{abstract}

Keywords: BPJS, Claims, Completeness, , Accuracy, Approval. 


\section{Pendahuluan}

Untuk mencapai jaminan kesehatan seluruh rakyat Indonesia, pemerintah membuat suatu sistem, yaitu Sistem Jaminan Sosial Nasional (SJSN). SJSN sendiri sudah diatur pada UU No. 40 Tahun 2004 dan sejalan dengan Jaminan Kesehatan Nasional (JKN). Prinsip pelaksanaan JKN sendiri merupakan bentuk kesetaraan untuk masyarakat dalam memperoleh pelayanan kesehatan. ${ }^{1}$ Program JKN adalah wujud implementasi dari UU No. 36 Tahun 2009 dengan Badan Pelaksana Jaminan Sosial (BPJS) Kesehatan sebagai pengelola sebagaimana yang diatur dalam UU No. 24 Tahun 2011. JKN pada Berdasarkan pada UU No. 36 Tahun 2009, JKN mengupayakan semua masyarakat sama-sama memiliki hak dalam mendapatkan akses pada pelayanan kesehatan yang aman, bermutu, dan terjangkau pada semua pelayanan kesehatan. $^{2}$ Pada pelaksanaan JKN di Indonesia, BPJS Kesehatan sebagai pengelola menanggung pembayaran pelayanan kesehatanan pasien kepada Fasilitas Kesehatan Tingkat Lanjut (FKTL) melalui Indonesia Case Base Groups (INA CBG's). ${ }^{3}$ INA CBG's adalah sebuah sistem pembayaran "paket" dengan menyesuaikan pada diagnosis penyakit yang diderita oleh pasien. FKTL akan memperoleh hasil pembayaran sesuai dengan tarif INA CBG's yang berasal dari hasil rata-rata besarnya biaya yang dikeluarkan oleh sekumpulan diagnosis penyakit. $^{4}$

Penentuan tarif biaya pelayanan kesehatan sudah disesuaikan dengan surat edaran nomor: IR.01.01/1.1/6401/2013 Tahun 2013 mengenai pelaksanaan INA CBG's. Penentuan biaya hasil pelayanan kesehatan yang harus diklaim bergantung pada ketepatan hasil pengodean diagnosis yang terdapat pada rekam medis dan INA CBG's. Klaim yang dimaksud ialah permintaan pembayaran biaya hasil pelayanan kesehatan oleh penyedia fasilitas kesehatan kepada BPJS Kesehatan. Pada proses penagihan klaim
JKN, penagihan diserahkan kepada pihak BPJS. Pengajuan pembiayaan dari pelayanan kesehatan ke BPJS dibutuhkan sebagai syarat klaim yang akan diajukan kepada verifikator. ${ }^{5}$

Pada pelaksanaan klaim dilakukan proses verifikasi terhadap persyaratan pengajuan klaim yang menjadi dasar penagihan biaya verifikasi. Proses verifikasi dilakukan oleh pihak BPJS Kesehatan setelah menerima berkas klaim dari fasilitas kesehatan atau pelayan kesehatan lalu berkas akan diverifikasi administrasi kepesertaan dan pelayanan kemudian menempuh verifikasi software INA CBG's berdasarkan pada standard International Statistical Classification of Diseases and Related Health Problem (ICD-10), selanjutnya formulir pengajuan klaim diserahkan pada BPJS Kesehatan untuk melakukan persetujuan klaim dan melakukan pembayaran kepada faskes atau yankes yang mengajukan klaim. ${ }^{1}$ Terdapat banyak kendala dalam pelaksanaan verifikasi klaim BPJS salah satunya adalah berkas klaim yang ditolak oleh verifikator. Jika penolakan atau pending dalam melakukan klaim meningkat, dapat mengganggu operasional Rumah Sakit tersebut. Seperti halnya kasus yang menimpa berbagai RSUD di Jakarta, sejumlah RSUD di Jakarta mengalami kendala operasional akibat BPJS Kesehatan terlambat membayar klaimnya dan mempengaruhi pasokan obat.

Beberapa kendala yang ditemukan dalam pelaksanaan JKN di fasilitas pelayanan kesehatan, salah satunya, adalah terkait pembiayaan seperti adanya keterlambatan pencairan klaim. ${ }^{6}$ Temuan terdahulu menunjukkan bahwa permasalahan pembayaran klaim oleh BPJS kesehatan berdampak pada terganggunya aliran kas di beberapa rumah sakit, lebih lanjut hal tersebut mengakibatkan adanya penundaan pembiayaan operasional rutin seperti pembayaran kewajiban pada pegawai dan pemasok, dan pembiayaan pemeliharaan yang dikurangi, serta berpengaruh pada 
kinerja pegawai dan ketersedian logistik pelayanan sebagaimana yang terjadi di RSUD Gunung Jati. ${ }^{6,7}$

Penelitian terdahulu menemukan 63 berkas tidak disetujui dan 63 berkas disetujui dari 138 rekam medis di RSUD Sukoharjo. ${ }^{8}$ Penolakan ini terjadi karena beberapa faktor, menurut Permenkes No. 28 tahun 2014 hal-hal yang mempengaruhi klaim BPJS yaitu berkas klaim tidak lengkap, isi berkas yang tidak sesuai dan waktu pengajuan berkas yang terlalu lama. Pengembalian berkas klaim sebagian besar karena berkas yang tidak lengkap yaitu sebanyak 36 berkas (36\%) dan pelayanan kesehatan yang tidak sesuai sebanyak 41 berkas (42\%) mengakibatkan penolakan yang berujung pada tertundanya proses pembayaran klaim BPJS pada fasilitas kesehatan. $^{9}$

Salah satu faktor yang menyebabkan klaim BPJS kesehatan ditolak dan dikembalikan oleh verifikator adalah karena ketidaklengkapan dokumen yang akan diajukan. ${ }^{10}$ Begitu pula dengan penelitian terdahulu lainnya dimana diperoleh nilai P-value sebesar 0.000 dan OR sebesar 540 yang artinya rekam medis yang lengkap memiliki peluang untuk memperlancar proses klaim sebesar 540 kali dibanding rekam medis yang tidak lengkap. $^{11}$ Kelengkapan informasi rekam medis dapat menjadi dasar disetujuinya penagihan biaya verifikasi oleh BPJS Kesehatan kepada penyedia fasilitas pelayanan kesehatan tingkat lanjut, sehingga biaya pelayanan yang sudah dikeluarkan akan dibayarkan tepat waktu oleh BPJS dan akan berdampak baik terhadap FKTL karena tidak mengalami kesulitan pada biaya operasional ataupun mengalami kerugian.

Di Indonesia, mayoritas rumah sakit $( \pm 65 \%)$ belum memberikan pengodean diagnosis yang tepat, jelas, dan lengkap berdasarkan ICD-10. ${ }^{12}$ Hasil temuan penelitian terdahulu menyatakan bahwa dari 44 berkas rekam medis, diperoleh nilai OR sebesar 9 yang artinya pengodean diagnosis obstetric yang tepat memiliki peluang untuk klaim BPJS yang lancar sebesar 9 kali apabila dibandingkan dengan pengodean diagnosis obstetric yang tidak tepat. ${ }^{13}$

Pengembalian berkas klaim pembayaran rawat inap yang berdasarkan kesesuaian dengan ketentuan administrasi pelayanan yaitu pengodean diagnosis penyakit bukan pengodean unbundling merupakan satu-satunya ketentuan administrasi pelayanan yang tidak sesuai. ${ }^{9}$ Jumlah tidak sesuai pada koding penyakit adalah 8 berkas (8\%), sejalan dengan penelitian Sebelumnya dimana hasil penelitian masih menemukan adanya ketidaktepatan hasil pengodean diagnosis penyakit dan tindakan medis yang dihasilkan petugas penginput kode rawat inap. ${ }^{14}$ Presentase ketepatan koding hanya sebesar 74,67\% dan hasil penelitian lain menunjukkan penentuan kode diagnosis penyakit yang tepat yaitu sebanyak 17 berkas rekam medis dengan penyakit gastroenteritis acute dan 63 berkas rekam medis dengan penentuan kode diagnosis penyakit gastroenteritis acute yang tidak tepat. ${ }^{15}$

Kelengkapan berkas pada pasien rawat inap meliputi kelengkapan informasi rekam medis yang harus dilengkapi serta ditandatangani oleh dokter penanggung jawab pelayanan kesehatan yang tidak sesuai seringkali disebabkan karena ketidaksesuaian antar lembar klaim dan resume medis seperti kode diagnosis dan tindakan tidak sesuai dengan ICD-10 dan 9CM. ${ }^{1}$ Rumah Sakit Umum Daerah (RSUD) Tangerang Selatan merupakan Rumah Sakit pemerintah tipe $C$ yang sudah beroperasi sejak 29 Maret 2012. Sebagai Rumah Sakit Umum tingkat Kota, RSUD Tangsel memiliki cakupan pasien yang banyak khususnya pasien BPJS. Dengan cakupan yang banyak dan dikeluarkannya kebijakan pengalihan jaminan eKTP Tangerang Selatan ke BPJS Kesehatan, maka potensi kesalahan atau penolakan klaim semakin besar.

Hasil studi pendahuluan yang dilakukan di RSUD Tangerang Selatan 
menunjukkan bahwa terdapat klaim BPJS pada pasien rawat inap dengan total biaya Rp 278.197.200, yang tidak disetujui atau dipending dari total pengajuan pada bulan November 2018 - Desember 2018 dikarenakan pelayanan kesehatan yang tidak sesuai, berkas tidak lengkap, dan berkas harus diperbaiki. Hal ini berdampak pada cashflow biaya operasional RSUD Tangsel yang terhambat. Oleh karena itu, RSUD Tangsel sebagai FKTL dipilih penulis sebagai tempat penelitian untuk menganalisa persetujuan klaim BPJS kesehatan pada pasien rawat inap berdasarkan alur pelaksanaan klaim di rumah sakit. Hal ini menunjukan bahwa ada hambatan dalam proses klaim oleh pihak BPJS sehingga dapat menghambat pembayaran klaim ke fasilitas kesehatan belum adanya publikasi yang dilakukan oleh BPJS Kesehatan mengenai persentase persetujuan klaim BPJS secara nasional membuat penelitian ini dapat menjadi salah satu referensi pembaca.

\section{Metode Penelitian}

Penelitian kuantitatif ini dilakukan dengan pendektan observasional deskriptif dengan desain studi cross sectional (studi potong lintang) dimana data mengenai variabel penelitian diambil pada waktu yang sama untuk melihat adanya suatu hubungan. ${ }^{16}$ variabel penelitian meliputi kelengkapan informasi, ketetapan diagnosis, dan persetujuan klaim BPJS. Populasi dalam penelitian ini ialah seluruh berkas rekam medis (total sampling) pada unit rawat inap di RSUD Tangerang Selatan pada bulan Januari 2019 sampai Maret 2019. Penelitian menggunakan metode pengambilan data total sampling yang berjumlah 922 sampel.

Pengambilan data dilakukan dengan telaah dokumen dan wawancara terstruktur untuk variabel kelengkapan informasi rekam medis dan ketetapan kode diagnosis utama. Penilaian dilakukan untuk melihat kesesuaian pengodean diagnosis utama penyakit pada pasien dengan kode yang telah ditentukan dalam buku panduan/software ICD-10 yang diterbitkan oleh WHO dan informasi rekam medis disesuaikan dengan Standar Operasional Prosedur Rekam Medis lalu disesuaikan dengan persetujuan klaim BPJS pada pasien tersebut. Persetujuan klaim BPJS dilihat berdasaran alur pelaksanaan klaim di Rumah Sakit Umum Tangerang Selatan.

Data dianalisa dengan analisis data univariat berupa angka persentase untuk mendeskripsikan variabel penelitian guna menggambarkan tujuan dalam penelitian. Uji etik sudah dilakukan oleh Badan Komisi Etik dari Fakultas Ilmu Kesehatan UIN Syarif Hidayatullah Jakarta dengan nomor

surat Un.01/F10/KP.01.1/KE.SP/05.06.017/2019

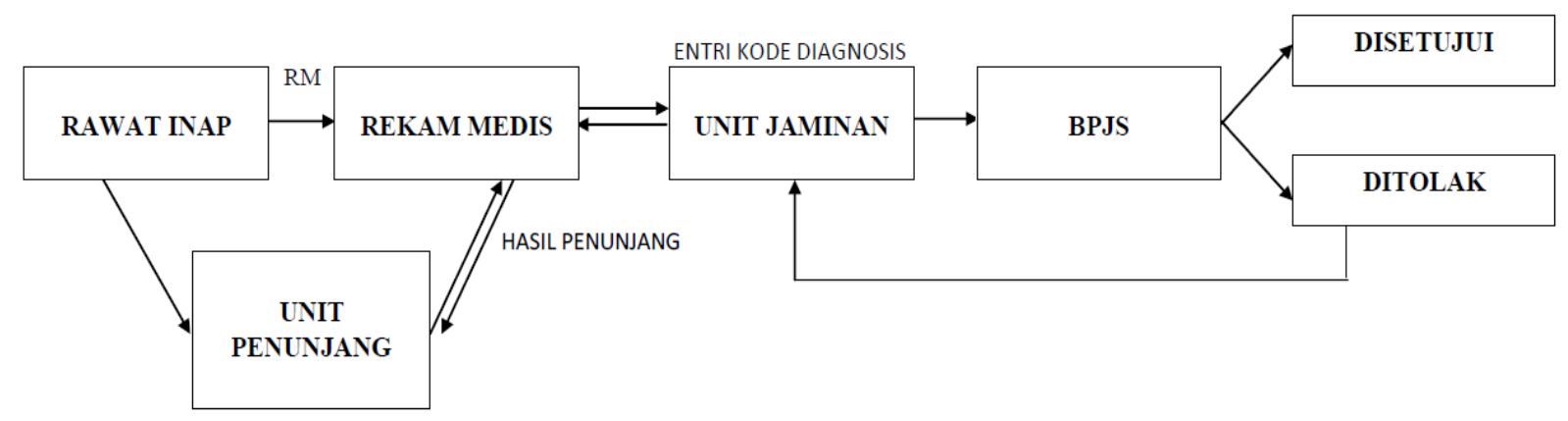

Gambar 1 Diagram Alur Pelaksanaan Klaim BPJS pada Pasien Rawat Inap di RSUD Tangerang Selatan 


\section{Hasil}

Tabel 1. Kelengkapan Informasi Rekam Medis pada Pasien Rawat Inap

\begin{tabular}{lcc}
\hline $\begin{array}{l}\text { Kelengkapan Informasi Rekam } \\
\text { Medis }\end{array}$ & n & \% \\
\hline Lengkap & 608 & 65,9 \\
Tidak Lengkap & 314 & 34,1 \\
$\quad$ Resume medis tidak lengkap & 133 & 42,4 \\
$\quad$ Hasil penunjang tidak ada & 181 & 57,6 \\
\hline
\end{tabular}

Berdasarkan Tabel 1, 65,9\% jumlah informasi rekam medis termasuk dalam kategori lengkap dan 34,1\% informasi rekam medis termasuk dalam kategori tidak lengkap. 57,6\% informasi rekam medis tidak lengkap karena lembaran resume medis yang tersedia tidak lengkap. Sedangkan $42,4 \%$ karena tidak adanya hasil penunjang pemeriksaan.

Tabel 2. Ketepatan Kode Diagnosis Utama dan persetujuan klaim BPJS Pasien Rawat Inap

\begin{tabular}{llll}
\hline Variabel & Kategori & n & \% \\
\hline Ketetapan kode & Tepat & 808 & 87,6 \\
diagnosis & Tidak tepat & 114 & 12,4 \\
Persetujuan klaim & Disetujui & 790 & 85,7 \\
BPJS kesehatan & Ditolak & 132 & 14,3 \\
\hline
\end{tabular}

Tabel 3. Jumlah Informasi Rekam Medis dan Kode Diagnosis Utama Berdasarkan Hasil Persetujuan Klaim BPJS Pasien Rawat Inap

\begin{tabular}{llcccc}
\hline \multirow{2}{*}{ Variabel } & \multirow{2}{*}{ Kategori } & \multicolumn{4}{c}{ Persetujuan Klaim BPJS } \\
\cline { 3 - 6 } & & \multicolumn{2}{c}{ Disetujui } & \multicolumn{2}{c}{ Ditolak } \\
\cline { 3 - 6 } & & 561 & 92,3 & $\mathrm{n}$ & $\%$ \\
\hline Kelengkapan Informasi & Lengkap & 229 & 72,9 & 85 & 7,7 \\
Rekam Medis & Tidak lengkap & 779 & 96,4 & 29 & 3,1 \\
Ketepatan Kode Diagnosis & Tepat & 11 & 9,6 & 103 & 90,4 \\
Utama & Tidak tepat & & & & \\
\hline
\end{tabular}

Berdasarkan Tabel 2, mayoritas diagnosis utama memiliki ketepatan kode diagnosis yaitu sebesar $87,6 \%$. Selain itu, $85,7 \%$ dari seluruh jumlah klaim BPJS yang diajukan selama periode JanuariMaret disetujui.

Pada tabel 3, mayoritas klaim dengan kelengkapan informasi rekam medis lengkap mendapatkan persetujuan yaitu sebesar 92,3\%. Pada kelompok informasi rekam medis dengan kategori tidak lengkap, 72,9\% klaim BPJS yang diajukan mendapatkan persetujuan. Berdasarkan tabel 3, 96,4\% klaim disetujui memiliki kode diagnosis utama yang tepat. Sedangkan dari kelompok dengan kode diagnosis utama yang tidak tepat, 9,6\% klaim BPJS mendapatkan persetujuan dan 90,4\% klaim BPJS tidak mendapatkan persetujuan.

\section{Pembahasan}

Temuan penelitian menunjukan informasi rekam medis yang tidak lengkap meliputi hasil lembar resume yang tidak lengkap dan hasil penunjang yang tidak tersedia. Resume medis yang tidak lengkap dikarenakan tidak adanya tanda tangan tenaga medis (dokter) penanggung jawab pasien, berdasarkan hasil wawancara dengan kepala unit Jaminan hal tersebut disebabkan pekerjaan resume medis harus dilakukan dokter, sehingga resume medis dapat terisi dengan lengkap termasuk tandatangan DPJP. Namun pada pelaksanaannya ada beberapa dokter yang tidak menandatangani lembar resume medis.

Pada hasil penelitian lembar resume tidak lengkap pada bagian tanda tangan DPJP sesuai dengan UU RI No. 29 tahun 2004 yang menyatakan setiap catatan rekam medis harus dibubuhi nama, waktu dan tanda tangan petugas yang memberikan pelayanan atau tindakan. ${ }^{17}$ Menurut penelitian terdahulu dokter yang menangani pasien pada unit rawat inap mempunyai kontribusi yang besar dalam kelengkapan pencatatan dan pengisian berkas rekam medis dan akan mempengaruhi proses pelayanan di rumah sakit, seperti pengklaiman yang dilakunan 
Unit Jaminan. ${ }^{18}$ Masalah tersebut terjadi karena kurang displinnya DPJP. Kedisplinan DPJP sangat diperlukan untuk mengurangi ketidaklengkapan informasi resume medis.

Hasil penunjang yang tidak lengkap disebabkan tidak adanya salah satu dari lembar hasil laboratorium, lembar Elektro Kardio Grafi (EKG), Rontgen, CT Scan, MRI, dan hasil penunjang lain di rekam medis. Merujuk pada Permenkes No.269/MENKES/PER/III/2008

disebutkan bahwa berkas rekam medis memiliki hasil penunjang medis jika digunakan. ${ }^{19}$ Berdasarkan wawancara dengan kepala Unit Jaminan disebutkan penyebab dari hasil penunjang tidak ada pada rekam medis adalah Unit terkait membutuhkan rekap hasil lab untuk Rumah Sakit dan petugas Rekam Medis tidak melakukan penyalinan hasil penunjang.

Hasil tersebut sesuai dengan Permenkes RI No. 40 tahun 2012 tentang Administrasi Klaim dan Pelaksanaan INA CBG's yang menyatakan informasi dan berkas yang ada pada rekam medis menjadi syarat pada pelaksanaan klaim di Rumah Sakit. $^{20}$

Hasil penelitian menunjukan 12,4\% diagnosis utama dengan kode ICD X tidak tepat. Dari hasil penelitian ini diperoleh temuan adanya ketidaktepatan dalam proses pengodean diagnosis penyakit. Hal tersebut dapat disebabkan oleh beberapa faktor seperti petugas entri kode seringkali hanya melihat ICD-10 volume 3 yaitu indeks daftar alfabet tanpa merujuk ke volume 1 untuk menentukan kode dan mengecek kembali pada daftar tabulasi dan kesalahan pada penentuan kode akhir yaitu penentuan tingkat keparahan karena akan menentukan tarif biaya, kode akhir atau kode karakter keempat pada ICD 10 merupakan kode tambahan. Sebagaimana aturan yang tercantum dalam buku ICD 10, kode tambahan wajib untuk dicantumkan pada diagnosis utama penyakit.

Dengan adanya kode karakter ke empat akan menghasilkan kode yang spesifik dan akurat.Kode tersebut menentukan tingkat keparahan suatu penyakit ditentukan oleh dokter penanggung jawab berdasarkan diagnosa utama dan komplikasi yang dialami pasien jika terdapat keraguan bagi verifikator BPJS maka BPJS Kesehatan dapat mengkonfirmasi penentuan tersebut yang dapat mengakibatkan penundaan dalam pembayaran.

Hasil penelitian menunjukan klaim BPJS rawat inap di RSUD Tangerang Selatan sebagian besar disetujui dengan klaim disetujui sebanyak 790 atau $85,7 \%$ dan klaim ditolak sebanyak 132 atau 14,3\%. Prosedur klaim BPJS pertama kali dimulai dari pengajuan berkas klaim BPJS, yang meliputi resume medis, hasil pemeriksaan penunjang, surat eligibilitas peserta, surat perintah rawat, salinan kartu BPJS, salinan kartu tanda pengenal (KTP), salinan kartu keluarga (KK), dan ringkasan pasien pulang, dari pihak rumah sakit kepada verifikator BPJS kesehatan. Berkas tersebut kemudian diverifikasi oleh verifikator BPJS kesehatan. Verifikasi dilakukan dengan cara mengecek kelengkapan berkas dan pembiayaan yang diakui oleh BPJS kesehatan. Hasil dari pengecekan adalah berupa keputusan persetujuan klaim BPJS.

Proses pengklaiman pembayaran BPJS memiliki tahapan-tahapan dimulai dari unit pelayanan fungsional atau instalasi pelayanan kepada unit rekam medis. Kemudian berkas diproses oleh koder dan diteruskan kepada verifikator independen untuk diverifikasi. Berkas klaim yang tidak lengkap nantinya akan dikembalikan, disertai dengan lampiran berkas bukti telah dilakukannya intervensi/penanganan kepada pasien, kepada pihak rumah sakit untuk dilengkapi. Hal ini sudah diatur dalam petunjuk teknis pelaksanaan verifikasi klaim BPJS Kesehatan.

Pada kelengkapan informasi rekam medis terdapat masalah yang salah satunya adalah tidak ada tanda tangan DPJP pada lembar resume medis. Hal tersebut 
berpotensi membuat klaim yang diajukan mengalami kendala, seperti petugas rekam medis harus melengkapi kembali tanda tangan DPJP yang mana membutuhkan waktu yang lama.Berdasarkan berkas yang dikembalikan Verifikator BPJS Kesehatan, dari 132 klaim yang ditolak 68 klaim atau $51.5 \%$ ditolak karena informasi rekam medis tidak lengkap dan dari 132 klaim yang ditolak, 57 klaim atau $43.5 \%$ ditolak karena kesalahan pada kode diagnosis.

Hal ini berkaitan dengan adanya lembar klaim yang tertera diagnosa utama penyakit dan intervensi yang telah diberikan serta pengodean pada masingmasing tidakan. Proses pengodean tersebut perlu diperhatikan karena kesalahan pengodean dapat berdampak pada terjadinya penolakan tarif. $^{21}$ Kode diagnosa penyakit menurut ICD-10 dan informasi rekam medis menjadi dasar penentuan besar biaya yang harus dibayarkan BPJS Kesehatan kepada fasilitas kesehatan, jika ada kesalahan pada informasi rekam medis yang menyebabkan kesalahan pada kode diagnosis akan menyebabkan perbedaan tarif klaim, nantinya akan diperiksa oleh verifikator BPJS jika tidak disetujui maka akan berdampak langsung bagi operasional fasilitan kesehatan.

Sejalan dengan hasil penelitian Pradani menurut data Instalasi Jaminan Pembiayaan Rumah Sakit $\mathrm{X}$ terdapat perbedaan antara nilai yang diajukan dengan nilai yang terealisasi yang cenderung meningkat. ${ }^{22}$ Perbedaan ini dapat diakibatkan oleh masih adanya berkas verifikasi yang yang kurang dan perlu diperbaiki. Hal ini berdampak pada penundaan dana yang turun untuk rumah sakit. Dana yang seharusnya selesai atau lunas pada tahap 2 mengalami keterlambatan dan diselesaikan atau dilunaskan pada tahap ke 3. Dalam penelitian lain disebutkan waktu pengajuan klaim merupakan salah satu faktor klaim ditolak, namun pada penelitian tersebut diketahui bahwa berkas klaim tersebut dibuat untuk pelayanan yang diberikan pada Bulan April tahun 2016, sedangkan pengajuan klaim baru dilaksanakan pada Bulan Juli tahun 2016. ${ }^{21}$ Berbeda dengan hasil penelitian yang dilakukan peneliti, yang mana klaim yang diajukan selalu tepat waktu diajukan pada tanggal 10 bulan selanjutnya setelah dilakukan pelayanan.

Berdasarkan Permenkes No. 28 Tahun 2014, pengajuan klaim oleh fasilitas kesehatan dilakukan setiap bulan dengan berkala dan pengajuan paling lambat adalah tanggal 10 pada bulan berikutnya. Berdasarkan hal itu, berkas klaim yang diajukan RSUD Tangsel tepat pada waktunya. Dalam Permenkes No. 28 Tahun 2014 juga disebutkan bahwa waktu pengajuan klaim oleh fasilitas kesehatan paling lambat adalah dua tahun setelah pelayanan diberikan kepada pasien. ${ }^{1}$ Hal ini menunjukkan bahwa proses pengajuan klaim tidak harus dilakukan tepat setelah penanganan kepada pasien rawat inap selesai dilakukan. Rumah sakit dapat mengajukan klaim BPJS beberapa saat hingga paling lama adalah dua tahun setelah penanganan pasien dilakukan.

Hasil penelitian ini menunjukan adanya rekam medis yang ditolak yaitu sebesar 47 klaim $(7,7 \%)$. Kelengkapan informasi menunjukan hasil kelengkapan serta akurasi dari data yang diajukan oleh pihak rumah sakit terhadap berkas-berkas informasi yang disyaratkan oleh BPJS kesehatan sebagai pihak yang dituju.

Dokumen pasien adalah salah satu faktor yang paling utama dalam proses pengklaiman BPJS kesehatan. Kelengkapan berkas pasien menyesuaikan pada tingkat akurasi pemberian jaminan pembiayaan oleh BPJS kesehatan. Petugas pada bagian klaim BPJS kesehatan harus memeriksa kelengkapan informasi pasien yang diatujukan untuk memvalidasi bahwa bantuan pembiayaan yang diberikan tepat sasaran dan sesuai dengan spesifikasi perawatan yang ditanggung oleh BPJS kesehatan. Dalam hal ini, dokumen rekam medis haruslah sesuai dengan tindakan pengobatan dan intervensi yang diperoleh pasien, termasuk juga pemeriksaan 
penunjang, karena berdampak pada naik turunnya tarif klaim BPJS.

Sementara itu, untuk klaim BPJS dengan informasi yang tidak lengkap,Hasil penelitian menunjukan dari total 314 klaim dengan informasi rekam medis yang tidak lengkap, terdapat 229 atau 72,9\% klaim yang disetujui, hal tersebut lebih besar daripada klaim yang ditolak yaitu 85 atau $27,1 \%$.Berdasarkan berkas yang dikembalikan Verifikator BPJS Kesehatan, dari 132 klaim yang ditolak 68 klaim atau $51.5 \%$ ditolak karena informasi rekam medis tidak lengkap. Setelah melakukan wawancara dengan kepala Unit Jaminan disebutkan hal tersebut terjadi karena pada beberapa status klaim yang tidak lengkap, unit jaminan membuat catatan untuk rekam medis mana saja dan apa saja yang tidak lengkap, setelah itu memberikan catatan tersebut kepada unit jaminan.

Dalam kasus diatas informasi rekam medis yang tidak lengkap adalah tanda tangan DPJP dan hasil lab atau penunjang. Setelah diberikan catatan untuk rekam medis yang tidak lengkap oleh jaminan, petugas rekam medis melengkapi informasi rekam medis dan memberikan kembali ke Unit Jaminan. Sementara peneliti hanya bisa melakukan pengambilan data pada rekam medis yang ada pada ruangan Unit Rekam Medis dan pada waktu informasi rekam medis belum dilengkapi.

Berdasarkan temuan penelitian, lebih banyak klaim yang disetujui dengan kode diagnosis utama yang tepat $(96,4 \%)$ dan jumlah klaim yang tepat namun ditolak sebesar 3,6\%. Pada hasil di atas jumlah klaim dengan kode diagnosis yang tepat lebih besar dibandingkan yang ditolak, hal tersebut dikarenakan pihak BPJS melihat kode ICD-10 yang diberikan untuk menentukan tarif pelayanan yang diberikan RS kepada pasien. Sejalan dengan penelitian yang telah dilakukan yang menunjukkan bahwa dari 44 berkas rekam medis, diperoleh nilai OR sebesar 9, artinya pengodean diagnosis obstetric yang tepat memiliki peluang untuk mendapatkan klaim BPJS yang lancar sebesar 9 kali dibanding pengodean diagnosis obstetric yang tidak tepat.

Pengodean diagnosis yang tepat terhadap tindakan yang dilakukan kepada pasien sangatlah penting karena memberikan kemudahan pelayanan kaitannya dengan penyajian informasi terutama dalam penentuan biaya pengobatan bagi pasien. Pengodean dilakukan oleh petugas koder sesuai dengan ICD-10. Hubungan antara ketepatan pengodean diagnosis penyakit dengan persetujuan klaim BPJS juga ditemukan pada penelitian terdahulu. ${ }^{23}$

Sementara itu, untuk klaim BPJS dengan kode diagnosis yang tidak tepat,Berdasarkan 114 sampel dengan kode diagnosis tidak tepat terdapat 103 atau 90,4\% yang ditolak, sedangkan klaim BPJS yang tidak tepat namun disetujui hanya 11 atau 9,6\% yang diterima. Jumlah klaim dengan kode diagnosis tidak tepat yang ditolak lebih besar dibandingkan dengan yang diterima. Berdasarkan berkas yang dikembalikan Verifikator BPJS Kesehatan, dari 132 klaim yang ditolak, 57 klaim atau $43.5 \%$ ditolak karena kesalahan pada kode diagnosis.

Pada penelitian ini kode diagnosa yang tidak akurat dapat menjadi masalah karena klaim BPJS Kesehatan tidak dapat dibayarkan karena melanggar ketentuan yang telah ditetapkan oleh BPJS Kesehatan. Dalam hal ini, apabila petugas koder melakukan pengodean diagnosis penyakit yang salah, maka akan berpengaruh pada jumlah pembayaran klaim yang berbeda dari pembayaran seharusnya. Ketidaktepatan hasil koding diagnosis penyakit dan tindakan medis yang dihasilkan koder rawat inap, persentase ketidaktepatan koding mencapai $25,33 \%$ yang berpengaruh dalam proses pengklaiman biaya pelayanan kesehatan. ${ }^{14}$ Tarif pelayanan kesehatan yang lebih murah dari seharusnya tentu akan berdampak pada kerugian pihak rumah sakit. Hal sebaliknya juga akan terjadi apabila tarif lebih besar dibandingkan 
dengan ketentuan tarif penyakit dalam INA-CBG's maka akan merugikan penyelenggara BPJS dan pasien.

Jika hal ini terus-menerus terjadi dan dalam jangka waktu yang lama, dampak lebih lanjut yang akan terlihat adalah penurunan pendapatan rumah sakit menjadi berkurang dan akan berdampak pada operasional rumah sakit yang terhambat. Oleh karena itu, agar sistem klaim BPJS Kesehatan dapat dijaminkan RSU Tangerang Selatan maka RSU Tangerang Selatan harus menjamin bahwa informasi yang tertera pada rekam medis sudah lengkap serta kode diagnosis penyakit yang dituliskan sudah tepat dan akurat sesuai ICD 10, sehingga klaim BPJS dapat disetujui dan dibayarkan tepat waktu. Penelitian terdahulu menemukan bahwa ada hubungan yang signifikan antara ketepatan reseleksi diagnosa penyakit dan kode utama diagnosa dokumen rekam medis dengan pembiayaan. ${ }^{24}$ Secara keseluruhan, temuan penelitian dijabarkan berdasarkan pada alur pelaksanaan klaim BPJS pada rawat inap di Rumah Sakit Umum Tangerang Selatan sebagaimana Gambar 2.

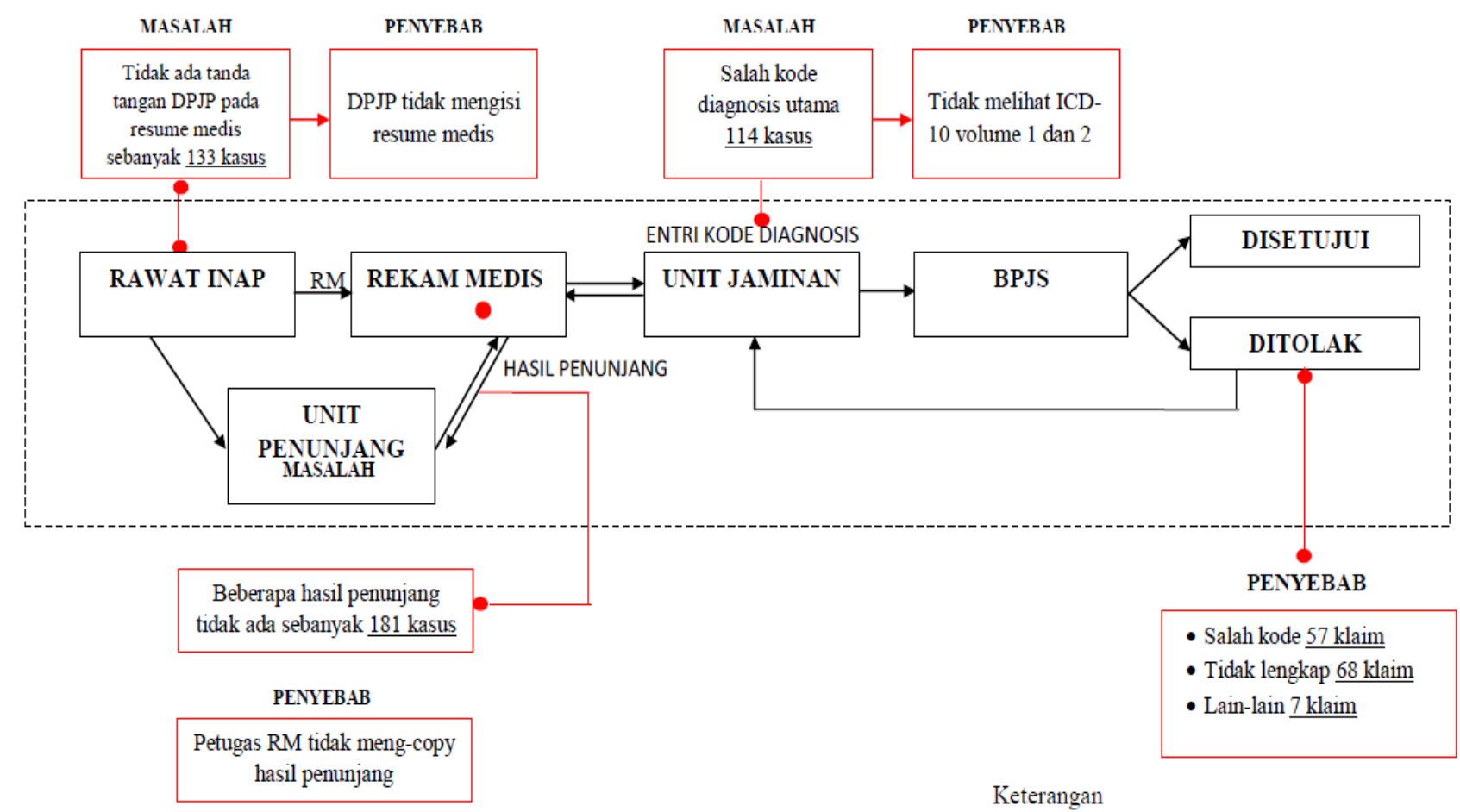

: Alur Pelaksanaan Klaim

Gambar 2. Hasil Temuan Penyebab Masalah Berdasarkan pada Alur Pelaksanaan Klaim BPJS pada pasien Rawat Inap di RSUD Tangerang Selatan

Keterbatasan pada penelitian ini adalah peneliti hanya melihat kelengkapan informasi rekam medis hanya berdasarkan data yang terdapat dalam ruang rekam medis. Keberadaan data diluar ruang rekam medis tidak dapat ditinjau oleh peneliti. Selain itu, pengambilan data yang tidak dapat dilakukan ketika data rekam medis telah dilengkapi juga tampaknya menjadi penyebab dari banyaknya data rekam medis yang tidak lengkap namun diterima sebagaimana yang tercantum pada tabel 3 .

\section{Kesimpulan}

Kelengkapan informasi rekam medis pada pasien rawat inap di RSU Tangerang Selatan cukup baik dimana presentase informasi rekam medis yang lengkap jumlahnya lebih besar daripada yang tidak lengkap begitupun dengan presentase kode diagnosis utama yang tepat jumlahnya 
lebih besar daripada yang tidak tepat, serta jumlah klaim yang diterima dengan informasi rekam medis yang lengkap dan kode diagnosis yang tepat lebih banyak daripada yang tidak lengkap dan tidak tepat.Namun masih ditemukan beberapa masalah yang disebabkan oleh faktor SDM, seperti kesalahan dalam penulisan kode diagnosis, tidak melakukan penyalinan terhadap hasil penunjang, dan dokter tidak menandatangani resume medis.

\section{Saran}

Berdasarkan hasil penelitian, maka terdapat beberapa saran yang dapat diberikan, untuk mengurangi kesalahan kode dan ketidaklengkapan informasi rekam medis, dapat melakukan pelatihan dalam penulisan diagnosis yang tepat dan sesuai standar bagi dokter, melakukan pelatihan secara berkala mengenai kode diagnosis yang benar menurut ICD 10 untuk petugas entri kode, dokter, tim verifikasi, petugas rekam medis, dan seluruh petugas medis yang terkait.

\section{Daftar Pustaka}

1. Kementerian Kesehatan RI. Peraturan menteri kesehatan Republik Indonesia nomor 28 tahun 2014 tentang pedoman pelaksanaan program jaminan kesehatan nasional. nomor 28 tahun 2014 Indonesia: Direktorat Jenderal Pelayanan Kesehatan Kementerian Kesehatan RI; 2014.

2. Sekretaris Negara RI. Undang-Undang RI nomor 36 tahun 2009 tentang program jaminan kesehatan nasional [Internet]. nomor 36 tahun 2009 Indonesia; 2009. Available from:

http://www.depkes.go.id/resources/download/ general/UU Nomor 36 Tahun2 009 tentang Kesehatan.pdf

3. Sekretaris Negara RI. Undang-undang RI nomor 24 tahun 2011 tentang badan penyelenggara jaminan sosial [Internet]. nomor 24 tahun 2014 Indonesia; 2011. Available from: http://www.bpjsketenagakerjaan.go.id/assets/u ploads/tiny_mce/PERATURAN/09012015_10 1207_uu_24_11_bpjs.pdf

4. BPJS Kesehatan. Seputar BPJS kesehatan [Internet]. BPJS Kesehatan. 2018 [cited 2018 Oct 12]. Available from: https://bpjskesehatan.go.id/bpjs/dmdocuments/eac4e7a83 0f58b4ade926754f74b6caf.pdf
5. Kementerian Kesehatan RI. Peraturan menteri kesehatan Republik Indonesia nomor 36 tahun 2015 tentang pencegahan kecurangan (fraud) pada pelaksanaan program jaminan kesehatan nasional. nomor 36 tahun 2015 Indonesia; 2015.

6. Putra wahyu manggala. Analisis Implementasi Kebijakan Jaminan Kesehatan Nasional di Rumah Sakit Umum Kota Tangerang Selatan 2017. Repos UIN Jakarta [Internet]. 2017; Available from: http://repository.uinjkt.ac.id/dspace/handle/12 3456789/25711

7. Halida M. Gambaran Klaim Peserta Jaminan Kesehatan Nasional Yang Ditolak di RSUD Gunung Jati, Cirebon, 2016. Repos UIN Jakarta. 2016;

8. Noviasari T, Sugiarsi S, Kusumawati Y. Hubungan kelengkapan informasi dengan persetujuan klaim BPJS di rsud kabupaten sukoharjo tahun 2016. J UMS [Internet]. 2016; Available from: https://eprints.ums.ac.id/45726/

9. Irmawati, Sugiharto, Susanto E, Astrianingrum M. Faktor-faktor penyebab pengembalian berkas klaim rawat inap oleh verifikator bpjs kesehatan di rsud tugurejo. ejurnal poltekkes semarang [Internet]. 2016; Available from: http://rmik.poltekkessmg.ac.id/wpcontent/uploads/2017/02/Faktor-FaktorPenyebab-Pengembalian-Berkas-KlaimRawat-Inap-Ole.pdf

10. Ardhitya T, Perry A. Faktor-faktor yang melatar belakangi penolakan klaim bpjs oleh verifikator bpjs di rsjd dr. Amino gondohutomo provinsi jawa tengah tahun 2015. e-jurnal Dinus [Internet]. 2015; Available from: eprints.dinus.ac.id , jurnal_15985\%0A

11. Harti T. Hubungan kelengkapan resume medis terhadap kelancaran klaim bpjs di rs qadr tangerang. J esa unggul [Internet]. 2016; Available from: https://digilib.esaunggul.ac.id/7692/UEUundergraduate-7692-BAB4-hubungankelengkapan-resume-medis-pasien-rawatinap-terhadap-kelancaran-klaim-BPJS-dirumah-sakit-qadr-tangerang.pdf

12. Kementerian Kesehatan RI. Profil Kesehatan Indonesia. Jakarta; 2008.

13. Izzah A. Hubungan ketepatan kode diagnosa obstetric terhadap kelancaran klaim bpjs di rsud sawerigading kota palopo sulawesi selatan. e-jurnal esa unggul. 2016;

14. Adhani W, Kristijono. Analisis ketepatan koding yang dihasilkan koder di rsud ungaran. e-journal poltekkes semarang [Internet]. 2016; Available from: ttp://ejournal.poltekkessmg.ac.id/ojs/index.php/jrk 
15. Karimah R, Setiawan D, Nurmalia P. Analisis ketepatan kode diagnosis penyakit gastroenteritis acute berdasarkan dokumen rekam medis di rumah sakit balung jember. $\mathbf{J}$ Univ jember [Internet]. 2016; Available from: https://jurnal.unej.ac.id/index.php/JAMS

16. Swarjana I. Metodologi Penelitian Kesehatan [Internet]. google book. Yogyakarta: ANDI; 2012 [cited 2018 May 10]. Available from: https://books.google.co.id/books?id=NOkOS2 $\mathrm{V} 7 \mathrm{vVcC} \&$ printsec $=$ frontcover $\& \mathrm{hl}=\mathrm{id} \# \mathrm{v}=$ onep age \&q\&f=false

17. Sekretaris Negara RI. Undang-Undang RI Nomor 29 Tahun 2004 Tentang Praktik Kedokteran [Internet]. nomor 24 tahun 2004 Indonesia; 2004. Available from: https://luk.staff.ugm.ac.id/atur/UU292004PraktikKedokteran.pdf

$2012 . \quad$ Available from: https://www.persi.or.id/images/regulasi/perme nkes/pmk402012.pdf

21. Catherine C. Handling The Medical Claim: An 8 Step Cuide On "How to" Correct And resolve Claim Issues. New york: CRC Press; 2013.

22. Pradani A, Lelonowati S. Keterlambatan Pengumpulan berkas Verifikasi Klamin BPJS di RS X:Apa Akar Masalah dan solusinya? J esa unggul [Internet]. 2017; Available from: http://digilib.esaunggul.ac.id/public/UEUUndergraduate-7478-ABSTRAK.pdf

23. Siswati siswati, Pratami S lindu. Hubungan
18. Yulia D. Analisis Kelengkapan Pengisian Resume Medis Pasien Rawat Inap RSIA Budi Kemuliaan Tahun 2008-2009. [Internet]. Universitas Indonesia; 2009. Available from: http://lib.ui.ac.id/file?file=digital/124735-S5711-Analisis kelengkapan-Literatur.pdf

19. Kementerian Kesehatan RI. Peraturan menteri kesehatan republik indonesia nomor 269/MENKES/PER/III/2008 tentang rekam medis. [Internet]. Dinkes Surabaya. 2008 [cited 2018 Nov 11]. Available from: http://dinkes.surabaya.go.id/portal/files/perme nkes/dok_dinkes_87.pdf

20. Kementerian Kesehatan RI. Peraturan Menteri Kesehatan Republik Indonesia Nomor 40 Tahun 2012 Tentang Pedoman Pelaksanaan Program Jaminan Kesehatan Masyarakat [Internet]. nomor 40 tahun 2012 Indonesia; Ketepatan Pemberian Kode Diagnosa dan Tindakan Terhadap Persetujuan Klaim BPJS. Indones Heal Inf Manag $\mathbf{J}$ [Internet]. 2015;3(2). Available from: https://ejurnal.esaunggul.ac.id/index.php/Inohi $\mathrm{m} /$ article/view/2092

24. Widyaningrum L. Ketepatan reseleksi diagnosa dan kode utama berdasarkan aturan morbiditas pembiayaan jaminan kesehatan INA-CBGs. J Manaj Inf Kesehat [Internet]. 2016; Available from: http://jmiki.aptirmik.or.id/index.php/jmiki/arti cle/view/81 